\title{
直動ボールガイドシステムの高精度化に関する研究 *
}

\author{
ーテーブル剛性がウェービング振幅値に与える影響について一 \\ 高 橋徹 ${ }^{* *}$ 野 口昭 治 ${ }^{* * *}$ \\ A Study to Enhance the Accuracy of Linear Motion Ball Guide System \\ -On the Influence That Table Stiffness Affect to the Value of Waving Amplitude- \\ Tohru TAKAHASHI and Shoji NOGUCHI
}

\begin{abstract}
I reported in previous paper that high precision arrangement in LMBG (Linear Motion Ball Guide) System is able to realize by introducing an art to optimize the crowning shape in both ends of raceway surface. This art was spread in industrial sector centering on Machine Tool. However, it was reported that high precision cannot be obtained with this art for the rare occasion. When I watched a number of real machines reported, it seemed that most of them were equipped with slim table. I thought that LMBG causes waving phenomena alone so that the connected table deformed infectiously, and consequently the waving amplitude did not become smaller and high precision could not be acquired. In this study, therefore, I performed an analysis which combined the load distribution theory and table deformation calculation so as to take account of table stiffness by LMBG model for the breakthrough of stiffness and waving relation. In conclusion, there found that the waving of LMBG alone transforms the table and there is a correlation between them. I led of the stiffness of LMBG and table design guideline so as to realize high accuracy including the challenge of table deformation from those relation. I report, in addition, the relation between the table stiffness and waving amplitude value were clarified through the experimental verification.
\end{abstract}

Key words : linear motion ball guide, load distribution, accuracy, high precision, crowning, waving, table stiffness

\section{1. 緒言}

前報1) で, 直動ボールガイド (LMBG: Linear Motion Ball Guide) システムにてコの字形状キャリッジの開口部変形を考慮した負 荷分布理論式をたて, 軌道面両端部のクラウニングとウェービ ングの関係を明らかにし，実験検証を経てウェービング振幅值 の最小值の存在を明らかにした. それにより, LMBG システム の高精度化が実現できるという内容を報告した. この技術は工 作機械分野を中心に広がりをみせ，静圧案内等には及ばないも ののそれ相応の好評価を受けている.

ところが，まれに本技術を適用しても高精度化されないとい う報告があがってきた．そこで，報告のあった実機を何台か見 てみると, 実際に LMBG を連結して使用されているテーブル (以降: 実機テーブル) の厚さが総じて薄いのではないかと感 じた. 一般的に工作機械分野では剛性を主目的の一つとしてい るため, 実機テーブルは鋳鉄製を採用し内部にリブ等を入れた 厚めの寸法となっていると認識していた. ところが近年では高 速化, 高サイクル化, コンパクト化, さらには低コスト化にも 重点が置かれ，実機テーブルが薄型軽量設計になってきている とのことであった.

内部構造を含めた実機テーブルの厚さが異なると剛性や質量 が異なるが, 着目したのは剛性である. そもそも LMBG は単体 でウェービング現象を起こすものなので, それにつられて連結 している実機テーブルが変形してしまっているのではないか, それゆえウェービング振幅值が小さくならず高精度化が実現で きなかったのではないかと考えた.

* 原稿受付 令和 2 年 3 月 22 日

掍載決定 令和 2 年 6 月 30 日

** 正 会 員 THK 株式会社（東京都大田区東糀谷 4-9-16)

*** 正 会 員 東京理科大学 (千葉県野田市山崎 2641)
さらに，工作機械以外の分野では剛性が主目的となっていな いことが多い. 例えば半導体製造装置等の分野では高速化, 高 サイクル化を主目的としているため, 軽量化重視で実機テーブ ルは総じて薄く, アルミニウム製を採用していることもある. これらすべての分野において高精度化が図られなければ LMBG システムの高精度化が実現できたとはいいきれない.

そこで本研究では, 実機テーブル剛性とウェービングの関係 を解明するために, LMBG システムモデルにて, 解析モデル用 連結テーブル (以降 : モデルテーブル) 剛性を考虑できるよう に負荷分布理論とモデルテーブル変形計算を連成した解析をお こなった. その結果, LMBG 単体のウェービングによりモデル テーブルは確実に変形しており, その両者には相関関係がある ことがわかった. それらの関係から，実機テーブル変形も含め た形で高精度化を実現するための, LMBG 部の剛性と実機テー ブルの設計指針を導いた. また, 実機テーブル剛性とウェービ ング振幅值の関係を実験検証により明らかにしたので報告する.

\section{2. モデルテーブル剛性を考慮したウェービング解析}

ウェービングは $2 \kappa D_{a}$ ストローク周期で生じるキャリッジに 対する相対玉位置の変化による負荷分布状態の変化から生じる 姿勢変位, ということは前報1 で明らかにしたとおりである. 図 1 に改めてその様子を示す. 用いた記号等は前報1) と同様の ため詳細説明は省略する. キャリッジ軌道面内の玉位置が, ス トロークとともに (a) (e) のように相対位置を変化させていき, 玉ピッチ $\kappa D_{a}$ の 2 倍となる $2 \kappa D_{a}$ ストロークすると元の (a) の 状態に戻る. この間, 軌道面内の玉位置は左右の対称性が変化 し, 外力やモーメントに対する力のバランスが変化し, その力 に応じた弾性変形量が変化し, キャリッジが姿勢変位を起こす ということである. そして, $2 \kappa D_{a}$ 周期でこれが絽り返される. すなわち LMBG は単体で, 上下 $\alpha_{1}$ 方向, 水平 $\alpha_{2}$ 方向, 口ー 
(a)

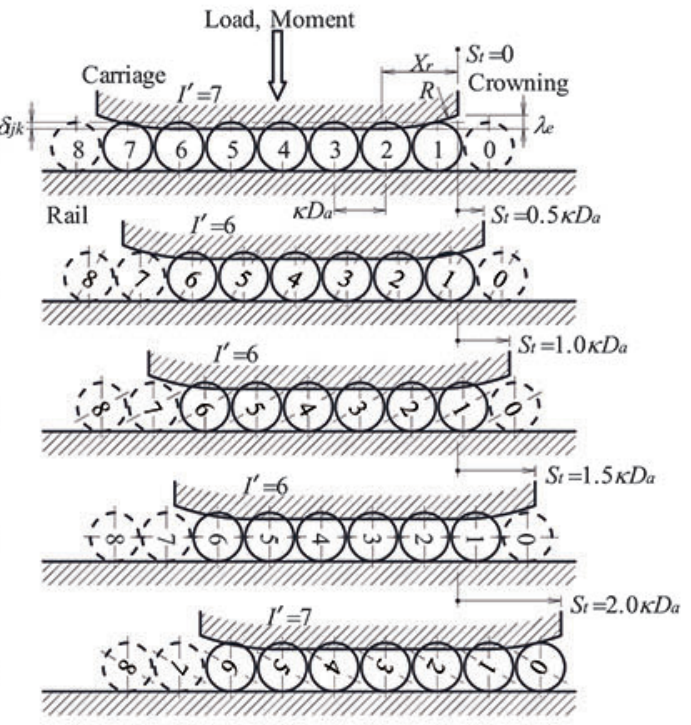

Fig.1 The relativity of carriage and ball position by stroke

リング $\alpha_{3}$ 方向, ピッチング $\alpha_{4}$ 方向， ヨーイング $\alpha_{5}$ 方向のウェー ビングを起こすものなのだが, これまでの研究では LMBG シス テムのモデルテーブル㓮性は無限大としていた，その理由は， LMBG の正面断面粠造は機械要素部品である正面組合せアン ギュラ玉軸受の正面断面構造と同等であり，内輪をレール，外 輪をキャリッジとし, 外輪の回転をキャリッジの移動方向に置 き換えた直線軸受といえるものである. すなわち自動調整能力 を備えており，実機テーブルを変形させるとは考えていなかっ たからである. したがって, 各キャリッジで生じているウェー ビングによる変位は実機テーブルを介して押さえ込まれてしま い, 主に個々のキャリッジが上下動する分くらいしか LMBG シ ステムとしての姿勢変位は現れないことになっていた． 前報り の実験で採用した実機テーブルは厚さ $80 \mathrm{~mm}$ ，中実の鋼製であ り,一般的に㓮性は十分高いと判断できるものである. しかし， 実際には剛性無限大ということはありえないため, 個々のキャ リッジが起こしているウェービングによる変位により, 実機テ ーブルは曲げモーメント等を受け変形していると考えられる.

実際には LMBG $の 5$ 方向のウェービングにより実機テーブ ルは3 次元的に変形している思われるが, 板状の実機テーブル 変形を考えたとき, 大きくは LMBG のローリング $\alpha_{3}$ 方向とピ ッチング $\alpha_{4}$ 方向によるものであると考えられる. しかし, LMBG は前述のような構造であるので, 特にローリング $\alpha_{3}$ 方向には接 点変動による自動調整能力が高く, 実機テーブルを変形させる ほどの大きなモーメントを生じさせないと考えられる.よって， 図 2 に示すような, レール 1 本，キャリッジ 2 個を中実のモデ ルテーブルで組み付けた LMBG システムモデルを設定して, ピ ッチング $\alpha_{4}$ 方向のみによるモデルテーブル変形を対象として 解析をおこなった. 座標原点を $y$ 軸方向 LMBG の中央とした以 外，用いた記号等は前報 ${ }^{1)}$ と同様のため詳細説明は省略する. LMBG は 4 章の実験に供した ISO \#25 Type としたが，詳細は 4 章に示す.

図 3 に $2 l_{x}=250$ として, ストローク中のキャリッジ単体のピ ッチング $\alpha_{4}$ 方向のウェービングによるキャリッジ傾きとモデ ルテーブル変形のイメージを示す. 添え字 1,2 はキャリッジ番 号 $k=1,2$ に準拠するものとし， $2 \kappa D_{a}$ ストローク内のある瞬間に おいて何の拘束もなくピッチング $\alpha_{4}$ 方向のウェービングを起

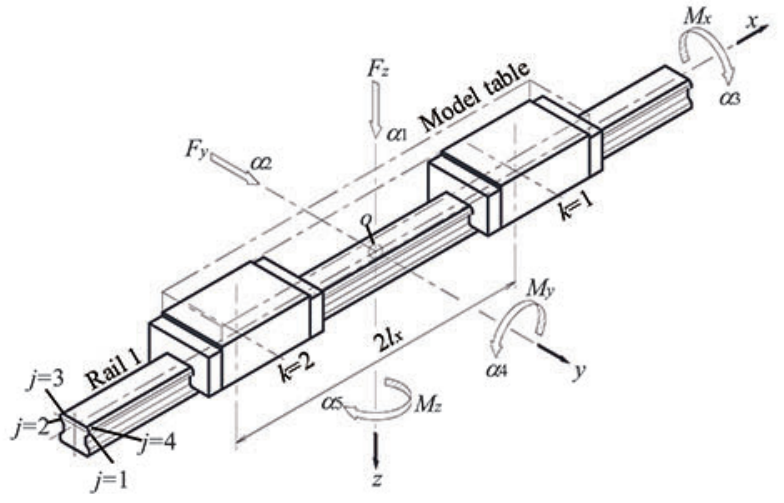

Fig.2 LMBG system for analysis

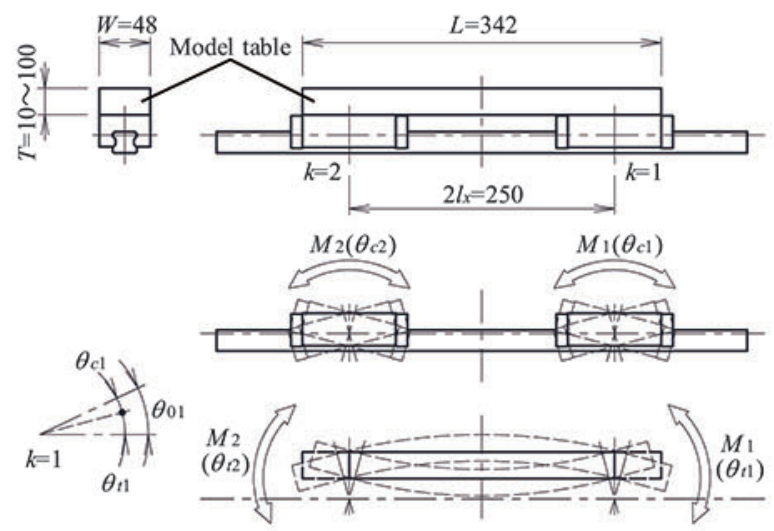

Fig.3 Analysis model

こして生じたそれぞれのキャリッジの傾きを $\theta_{01}, \theta_{02}$ ，各キャリ ッジ部に生じた不静定モーメントを $M_{1}, M_{2}$ とすれば, 不静定モ 一メントによって変位したキャリッジ側の傾き角を $\theta_{c 1}, \theta_{c 2}$, モ デルテーブル側の傾き角を $\theta_{t} 1, \theta_{2}$ とすると, 図 3 に示すように これらの間にはつぎの関係が成り立つ.

$$
\begin{aligned}
& \theta_{01}=\theta_{c 1}+\theta_{t 1} \\
& \theta_{02}=\theta_{c 2}+\theta_{02}
\end{aligned}
$$

この (1), (2) 式を同時に満たす不静定モーメントを求めること によりモデルテーブル変形が求められる. $\theta_{c 1}, \theta_{c 2}$ は LMBG 負 荷分布理論より求め, $\theta_{t}, \theta_{i}$ は, 図 3 で示した幅 $W$, 長さ $2 l_{x}$, 厚さを $T$ とした “はり”において両端にモーメントが作用した ものとして求める. この解析を $2 \kappa D_{a}$ ストロークを 50 分割した 位置でおこなうことによりモデルテーブルが上下に変形してい る状態を表現できる.

図 4 に, LMBG のオーバーサイズ量 $\lambda=8 \mu \mathrm{m}$ 予圧付与品に て, モデルテーブル材質をヤング率 $205 \mathrm{GPa}$ の鋼 S45C とし, $T=10,20,40,60,80,100 \mathrm{~mm}$ としたときの解析結果を示す. ここ でオーバーサイズ量とは，レールとキャリッジの 4 つの玉列の 軌道面間寸法はちょうど玉径に設計されているが, LMBG の剛 性向上等を目的として，そこへ少し寸法の大きな玉を組み込む ことで予圧を付与させている. その設計上の玉径に対して玉径 を少し大きくした量のことである. グラフは横軸の両端にキャ リッジ中心がくるという表現をした. これよりモデルテーブル が変形している状況が確認でき，モデルテーブル厚さが $T=10$ $\mathrm{mm}$ から $T=100 \mathrm{~mm}$ へと厚くなっていくにしたがってモデルテ 一ブル変形が小さくなっていく様子が確認できる. 実機におけ る $\mathrm{LMBG}$ システムのウェービングは, このモデルテーブル変形 のように実機テーブルが変形した分が加算されて現れているの 


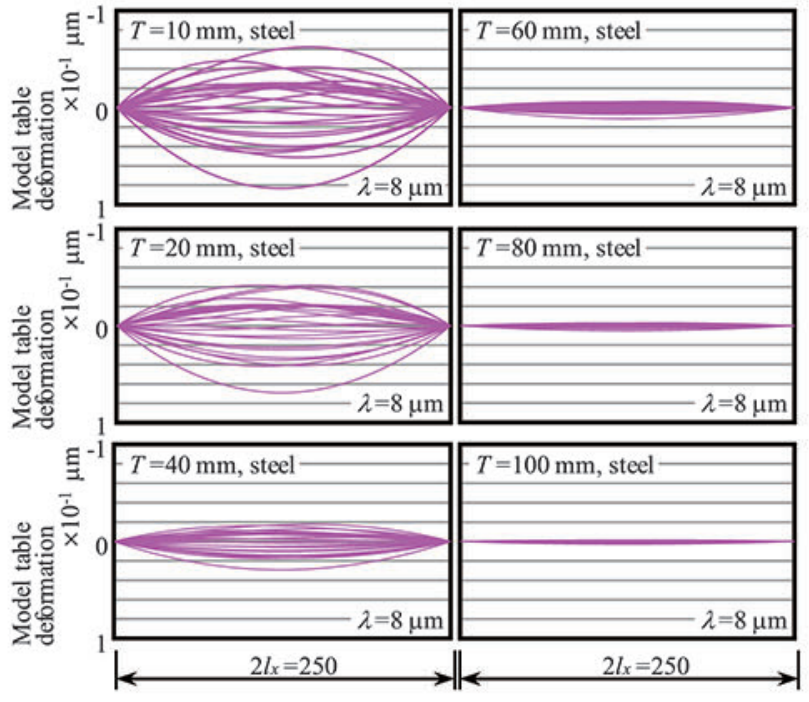

Fig.4 Model table deformation analysis of various model table thickness between each carriage

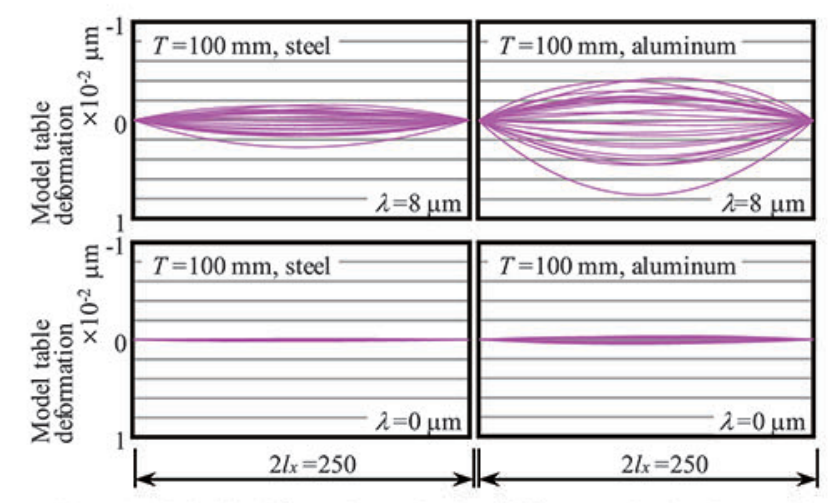

Fig.5 Model table deformation analysis of different preload and material between each carriage

で, モデルテーブル厚さ, すなわち剛性が LMBG システムのウ エービングに大きく関与していることがわかる.

図 5 には, $T=100 \mathrm{~mm}$ のモデルテーブルで材質にヤング率 205 $\mathrm{GPa}$ の鋼 S45C と同 $70.6 \mathrm{GPa}$ のアルミニウム合金 $\mathrm{A} 5052, \mathrm{LMBG}$ のオーバーサイズ量 $\lambda=8 \mu \mathrm{m}$ の予圧付与品と $\lambda=0 \mu \mathrm{m}$ の 0 す きま品における解析結果を示す.これより同じ予圧付与品にお けるモデルテーブル材質違い，すなわち剛性違いでは，想定ど おり剛性が高いほどモデルテーブル変形は小さいことがわかる ところが，0すきま品の場合モデルテーブルの剛性にあまり影 響されず変形は小さい. これは, LMBG 部の剛性が予圧付与品 よりも 0 すきま品の方が低く，モデルテーブルを変形させるだ けの前述の不静定モーメントが生じなかったからである.

モデルテーブル変形の形状が上下·左右対称とならないのは, LMBG が起こしているウェービング周期はそれぞれは $2 \kappa D_{a}$ だ が, その位相はキャリッジ番号 $k=1,2$ でずれており, 対称でも ない. よって, モデルテーブル両端に生じた 2 種類の不静定モ ーメントは, $2 \kappa D_{a}$ ストロークを 50 分割した各瞬間において全 く異なっているからである.

以上より，個々のキャリッジが起こしているピッチング $\alpha_{4}$ 方 向の変位により, モデルテーブルは曲げモーメントを受け変形 していることがわかった．また，その量はモデルテーブル剛性 と LMBG 部の剛性とのバランスで決まるということもわかっ た.

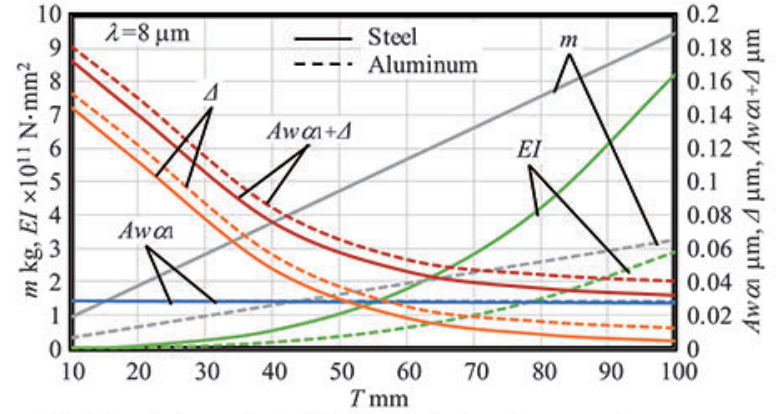

Fig.6 Analysis result in LMBG with $\lambda=8 \mu \mathrm{m}$ in terms of model table thickness $T$ and mass $m$, flexural rigidity $E I$, waving amplitude $A w \propto$, model table deformation $\Delta, A w \alpha 1+\Delta$

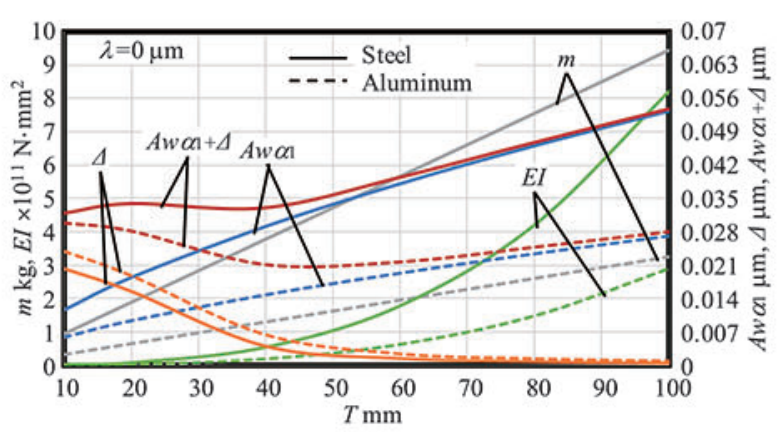

Fig.7 Analysis result in LMBG with $\lambda=0 \mu \mathrm{m}$ in terms of model table thickness $T$ and mass $m$, flexural rigidity $E I$, waving amplitude $A w \propto$, model table deformation $\Delta, A w \propto 1+\Delta$

\section{LMBG システムの実機テーブル設計指針・手法}

2 章で述べた内容をもとに, モデルテーブル厚さ, モデルテ ーブル質量，モデルテーブル曲げこわさ，モデルテーブルを剛 体とした LMBG システム中央直上のウェービング解析值, モデ ルテーブル変形量, の関係から, モデルテーブル変形を含めた 状態で LMBG システムの高精度化を実現するために有効な, LMBG 部の剛性とモデルテーブル設計の関係を構築できる.

図 2 に示した LMBG システムにて 2 章で解析したデータを もとに関係グラフを描く. 横軸にモデルテーブル厚さ $T \mathrm{~mm}$, 左縦軸にモデルテーブル質量 $m \mathrm{~kg}$ ，モデルテーブル曲げこわさ $E I \mathrm{~N} \cdot \mathrm{mm}^{2}$, 右縦軸にモデルテーブルを剛体とした LMBG シス テム中央直上のウェービング解析值 $A w \alpha_{1} \mu \mathrm{m}$, モデルテーブル 変形量 $\Delta \mu \mathrm{m}$, モデルテーブル変形を含めたウェービング振幅 值であるその両者の和 $A w \alpha_{1}+\Delta \mu \mathrm{m}$ の関係を, モデルテーブル材 質を銅とアルミニウム合金の 2 種類として, 図 6 に $\lambda=8 \mu \mathrm{m}$ の LMBG のき, 図 7 に $\lambda=0 \mu \mathrm{m}$ の LMBG のときについてそれ ぞれ示す.なお, 鋼は実線, アルミニウムは破線で示す. また, 図 6 と図 7 では右縦軸の数值が異なる.

図 6 の予圧を付与した LMBG システムにおいて, 鋼, アルミ ニウムとも, モデルテーブル厚さ $T$ に比例してモデルテーブル 質量 $m$, モデルテーブル曲げこわさ $E I$ が増加していき, モデル テーブル変形量 $\Delta$ が減少していく様子がわかる. モデルテーブ ルを剛体としたウェービング解析值は, モデルテーブル厚さや 質量の影響をあまり受けずほぼ一定值である. これより，モデ ルテーブル厚さとモデルテーブル変形を含めたウェービング振 幅值の関係がわかり, 安定した系であることもわかる. また, 質量の影響もあるが, 詳細は 4,5 章で述べる.

これより, 実現したいウェービング振幅值を右縦軸から左に たどり, $A w \alpha_{1}+\Delta$ 線との交点から下にたどりモデルテーブル厚 
さを求め, そのモデルテーブル厚さにおけるモデルテーブル曲 げこわさと同等になるように実機テーブルを設計すればよいと いう指針が示せる. 例えば, 図 2,3 で示した状態の LMBG シス テムを実機で製作する場合, 実現したいウェービング振幅值が $0.06 \mu \mathrm{m}$ だとすると, $A w \alpha_{1}$ が $0.06 \mu \mathrm{m}$ のところから, 鋼製実機 テーブルを使用するなら実線の $A w \alpha_{1}+\Delta$ 線との交点から下にた どり, モデルテーブル厚さ $T$ が約 $50 \mathrm{~mm}$ となり, そのときのモ デルテーブル曲げこわさ $E I か ゙ ~ 1 \times 10^{11} \mathrm{~N} \cdot \mathrm{mm}^{2}$ となるように実機 テーブルの断面設計をおこなえばよい.

ところが, 図 7 の予圧を付与していない LMBG システムにお いては, モデルテーブル質量 $m$, モデルテーブル曲げこわさ $E I$ は図 6 の予圧を付与したときと同じであるが, 図 5 で一部示し たようにモデルテーブル変形は小さく, モデルテーブル厚さ $T=50 \mathrm{~mm}$ 以上ではほとんど確認できないほどとなっている. モ デルテーブルを剛体としたウェービング解析值は, 龬とアルミ ニウムで異なり, どちらもモデルテーブル厚さに比例して大き くなっている. 予圧を付与されていない LMBG は, 軌道面内の 玉荷重はモデルテーブルの質量からしか作用しないため, その 弾性変形量は予圧付与の場合と比べかなり小さい. よって, 荷 重変動による姿勢変位, すわちウェービング振幅值そのものが 小さいが, 質量の増加とともに, 玉荷重の増加, 弾性変形量の 増加, 荷重変動量の増加, 姿勢変位量の増加とつながり, ウェ ービング振幅值が大きくなっていったといえる. その結果, モ デルテーブル変形を含めたウェービング振幅值 $A w \alpha_{1}+\Delta$ は, 鋼 とアルミニウムでは傾向が異なるが, どちらも単純比例とはな っておらず極小值を示すような関係となっている.このことか ら本解析は安定した系とはなっていないことがわかる. 寸なわ ち, 実現したいウェービング振幅值に対してモデルテーブル厚 さが 2 種類存在するといったことが起こり一意的に求めること はできない. よって, 予圧を付与していない場合には設計指針 を示せたとはいえない. この理由は, モデルテーブルを剛体と したウェービング解析值が質量に影響をうけて大きくなってい くことに他ならない. 予圧を付与して予圧量を増やしていけば, モデルテーブルを剛体としたウェービング解析值は質量に影響 をうけずほぼ一定の值となっていく. したがって, 本設計指針 は予圧を付与することが前提といえる.

ただし, 予圧を付与していない場合でも, 本解析結果は, 場 合によってはモデルテーブル厚さが 2 種類存在することにはな ってしまうが, 他の要因としての質量の影響を考慮して, 最適 な方を設計者が選択するという方法としては利用できる. また, 質量がかわるような設計変更をしながら本解析を繰り返しおこ なっていき, 最終的に実機テーブルを設計するという方法とし ても利用できる.

また, 予圧の有無に関わらず, モデルテーブル厚さが増して モデルテーブル曲げこわさが上昇していくと, モデルテーブル を剛体としたウェービング解析值に漸近していく様子もわかる.

本解析は図 2 に示した LMBG システムにおけるものだが,一 般的な構成であるレール 2 本, キャリッジ 4 個からなる LMBG システムでも解析は可能である. まず, モデルテーブルを剛体 として最適なクラウニング形状を求め, ウェービング解析を実 施する. つぎに, モデルテーブル変形を考虑したウェービング 解析を実施しモデルテーブル変形量を算出する. ここでもピッ チング $\alpha_{4}$ 方向のみによる変形量を算出しておいて差支えない と考える. その後は上記手法に則ればよい. この解析は, レー ル本数, キャリッジ個数に制限は受けず, あらゆる LMBG シス
テムに適用できる.

したがって, 予圧を付与することを前提とした LMBG システ ムを設計する際の指針を以下のように示せる. まず使用される 機械に求められる仕様から, 実機テーブルの長さ $\times$ 幅寸法を決 める. つぎに求める剛性や寿命から, LMBG の型式, サイズ, 予圧量を決め, 上記実機テーブル寸法などからレール間距離, キャリッジ間距離を決める. ここで, 解析結果が安定した系と なっていることを確認する必要がある. 確認できたら, 最後に 実現したいウェービング振幅值から, 本解析を適用して必要な モデルテーブルの曲げこわさを求め, その值になるように実機 テーブルの材質および断面設計をおこなう.

もし上記で安定した系とならなかった場合, さらに求める機 械仕様により元々予圧を付与しないことを前提としている場合 には, 解析結果が単純比例とはならず最小值が存在するような 関係となってしまうので, もし, 求めるモデルテーブル厚さが 2 種類存在するような場合には, 質量の影響を考慮しながら設 計者が最良の方を選択するという方法とする. さらに, 質量等 を変更して解析を繰り返すことにより，最終的に実機テーブル 設計を完了させてもよい.

この設計指針・手法に則って LMBG システムを設計すれば, 工作機械から一般産業機械まで幅広い分野で, 無䭾がなく効率 的に LMBG システムの高精度化が実現できる.

ただし, 実機テーブルが変形してウェービング振幅值が増加 することに対する実機テーブル設計指針・手法であるので, モ デルテーブルを剛体とした LMBG システムの最適クラウニン グ形状にて得られるウェービング振幅值以下にすることはでき ない.

\section{4. 実験}

図 8 に実機テーブル剛性とウェービング振幅值の関係を検証 するために用いた実験装置の概略を示す. LMBG を 1 軸実機テ ーブルに組み付けた LMBG システムで, 実機テーブル剛性の影 響を確認するために 3 種類の中実の実機テーブルを用意した. すべて長さ $340 \mathrm{~mm} \times$ 幅 $280 \mathrm{~mm}$ で, 厚さ $T=100 \mathrm{~mm}$ の鋼製, $T=20 \mathrm{~mm}$ の鋼製とアルミニウム製，質量は $T=100 \mathrm{~mm}$ 鋼製が約 $75 \mathrm{~kg}, T=20 \mathrm{~mm}$ 鋼製が約 $15 \mathrm{~kg}, T=20 \mathrm{~mm}$ アルミニウム製が約 $5 \mathrm{~kg}$ である. 駆動には LMBG システムの $x$ 軸方向と並行に設置 した 1 軸アクチュエータを用いた. 駆動装置そのものの影響を 受けにくいように直接の固定ではなく実機テーブル端部にロー ドセルを設置し，1 軸アクチュエータから伸ばした連接棒にて ロードセルを押す方法とした. さらに実機テーブル移動時の振 動等の影響も受けにくくするために極力低速にて駆動を与えた. 実機テーブル変形が最大に生じるのは実機テーブル中央付近と 考えられるので, 非接触変位計の測定位置を実機テーブル中央 に, マグネットスタンドの固定位置も極力実機テーブル中央部 に近くなるように固定した. そして定盤に固定した台座から伸 ばしたアームに直定規を設置して LMBG システムの姿勢変位 を測定した. 表 1 に測定条件と使用機器を, 表 2 に実験に用い た LMBG 仕様を示す. LMBG は予圧を付与したもので前報1) と 同タイプ, LMBG システムも前報1) と同条件であるので, クラ ウニング形状はそのときの最適形状であった深さ $\lambda_{e}=D_{a} / 350$, 長 さ $X_{r}=3.0 D_{a}$ を採用した.

図 9 に測定子の $z$ 方向の動きを測定し, ストローク始点と終 点を 0 に合わせて表記した結果を示す. 測定値の上下の幅が実 機テーブルの走り真直度を表す. これより, ウェービングと思 


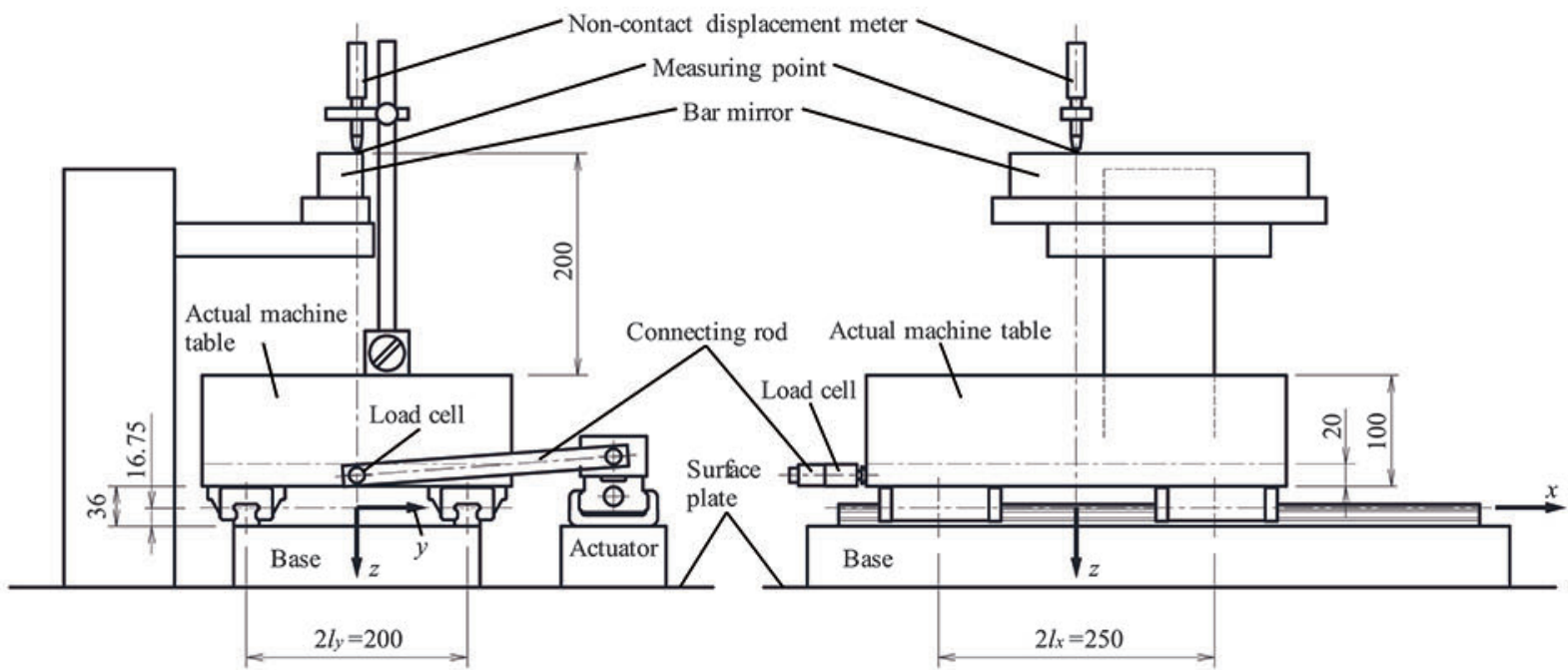

Fig.8 Outline drawing of LMBG system for experiment

Table 1 Measurement condition and Instrument used

\begin{tabular}{c|c}
\hline Feed device & KR4510/THK CO.,LTD. \\
Feed rate & $1 \mathrm{~mm} / \mathrm{s}$ \\
Stroke & $150 \mathrm{~mm}$ \\
Straightedge & Bar mirror $/$ NITTO OPTICAL CO.,LTD. \\
Displacement & Non-contact displacement meter \\
meter & $/$ Japan Laser Corporation \\
Recorder & $8840 /$ HIOKI E.E. CORPORATION \\
\hline
\end{tabular}

Table 2 LMBG specification

\begin{tabular}{c|c}
\hline Type & ISO \#25 \\
Ball diameter & $D_{a}=3.969 \mathrm{~mm}$ \\
Oversize volume & $\lambda=0.008 \mathrm{~mm}$ \\
Ball pitch & $\kappa D_{a}=4.27 \mathrm{~mm}$ \\
Comformity factor & $f=0.515$ \\
Carriage length & $2 u_{x}=71.0 \mathrm{~mm}$ \\
Pitch of circulations & $2 u_{y}=23.172 \mathrm{~mm}$ \\
& $2 u_{z}=6.436 \mathrm{~mm}$ \\
Initial contact angle & $\gamma=45^{\circ}$ \\
Crowning shape & $\lambda_{e}=D_{a} / 350$ \\
& $X_{r}=3.0 D_{a}$ \\
\hline
\end{tabular}

われる細かな振幅の大きさが, 鋼 : $T=100 \mathrm{~mm}<$ 鋼 : $T=20 \mathrm{~mm}<$ アルミニウム: $T=20 \mathrm{~mm}$ の関係にあることが確認できる.LMBG は全く同一であるので, 実験条件から考えて, 解析でシミュレ ーションしたとおり個々のキャリッジが, 主にピッチング $\alpha_{4}$ 方 向の変位を生じたときに発生した不静定モーメントによって実 機テーブルが変形していることの現れであると考えられる. 真 直度に関しては龬 : $T=100 \mathrm{~mm}$ だけが他と比べて大きく下凸の 形状となっていた. この理由については 5 章で考察する.

これから 3 種類の実機テーブルによる実験データのウェービ ングに関する各種比較分析をおこなっていくが, 鋼 : $T=100 \mathrm{~mm}$ だけ下に凸形状となったままおこなうと正しい比較分析ができ ないと考えられるので, 鋼 : $T=100 \mathrm{~mm}$ を鋼 : $T=20 \mathrm{~mm}$, アルミ ニウム : $T=20 \mathrm{~mm}$ 一近づける補正をしていく. それは, それぞ れの実験データから大きなうねり成分を取り出し, 鋼: $T=100$ $\mathrm{mm}$ と, 鋼 : $T=20 \mathrm{~mm}$ とアルミニウム : $T=20 \mathrm{~mm}$ の平均との差 分を元の鋼 : $T=100 \mathrm{~mm}$ のデータから差し引く方法とした.

図 10 に, 図 9 で得られた結果から, 小さなうねり成分を除去 して大きなうねり成分だけを取り出した結果と, そこから鋼 :
$T=20 \mathrm{~mm}$ とアルミニウム : $T=20 \mathrm{~mm}$ の平均を示す. 大きなうね り成分とは, 粗さ測定時に得られた断面曲線から得られるうね り曲線のことで,ここでは簡易的にうねり曲線と同等の結果を 得られる次式による移動平均という手法より導いた.

図 9 の結果を

$$
y=f(x)
$$

とし, 移動平均は, $x$ に対応する $y$ 值を, $x$ の前後任意の值 $x_{t}$ よ り $x-x_{t} \sim x+x_{t}$ 間の平均値とすることにより求める. $x_{t}$ に適当な 数值を入力しながらグラフを見て, 最も平滑なうねり成分が得 られる值を探していく. 今回は $x_{t}$ を $2 \kappa D_{a}$ 近辺の数值としたとき が最も適していたので $x_{t}=2 \kappa D_{a}$ とした. よって移動平均を $y_{\text {average }}$ とすれば

$$
y_{\text {average }}=\frac{1}{2 x_{t}} \sum_{k=x-x_{t}}^{x+x_{t}} f(k)
$$

と表せる. このようにして得られたうねり成分の鋼 : $T=100 \mathrm{~mm}$ と, 鋼 : $T=20 \mathrm{~mm}$ とアルミニウム : $T=20 \mathrm{~mm}$ の平均値との差分 を, 図 9 における鋼 : $T=100 \mathrm{~mm}$ から差し引くことで, 下に凸 形状となっていたデータを補正できる.

図 11 に, 図9 の鋼 : $T=100 \mathrm{~mm}$ を補正したデータを鋼 : $T=20$ $\mathrm{mm}$ とアルミニウム : $T=20 \mathrm{~mm}$ とともに示す. これにより大き なうねり成分がほぼ同一の 3 種類の実機テーブルのデータとみ なせる.

図 12 に図 11 で得られたデータを各種分析した結果を示す. それぞれ内容は以下の通りである.

(a) 図 11 のデータから前述の方法にてうねり成分を取り出 し, 元データからそのうねり成分を差し引き小さなうね り成分のみを取り出した結果. ほぼウェービングを示す ものと考える.

(b) (a) を波長解析した結果.

(c) (a) $の x=10 \sim 140$ において, 各 $x$ 值の前後 $\kappa D_{a}$ 間, $x-\kappa D_{a}$ $\sim x+\kappa D_{a}$ 間, すなわち $2 \kappa D_{a}$ 範囲内での最大值と最小值の 差を示した結果. ほぼウェービング振幅值を示すものと 考える.

これより本 (a) 図を $y_{\text {waving }}$ とすれば

$$
y_{\text {waving }}=y-y_{\text {average }}
$$

で表せる. なお, $x \leqq 0,150 \leqq x$ の範囲は $x=0, x=150$ の $y$ 值と 同值とした. 


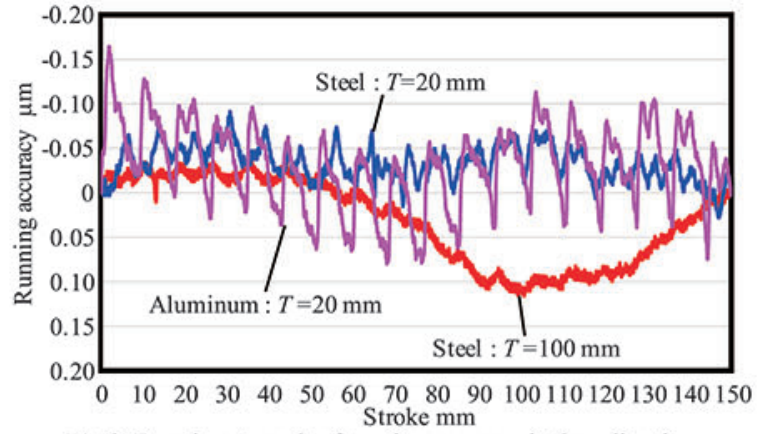

Fig.9 Experiment result of running accuracy in the $z$ direction

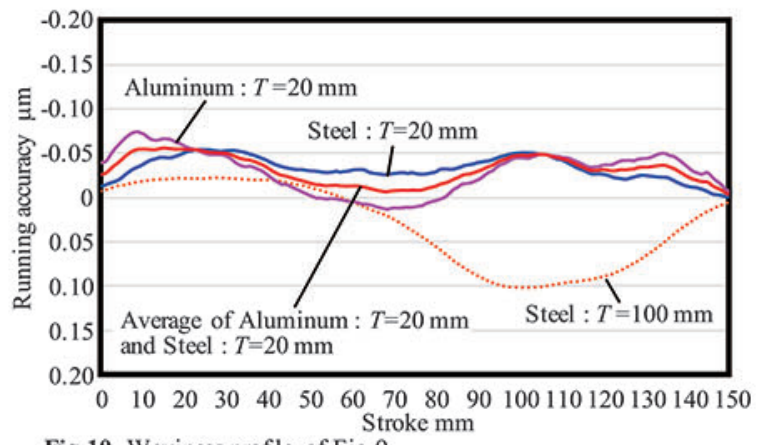

Fig.10 Waviness profile of Fig.9,

and average of aluminum : $T=20 \mathrm{~mm}$ and steel : $T=20 \mathrm{~mm}$

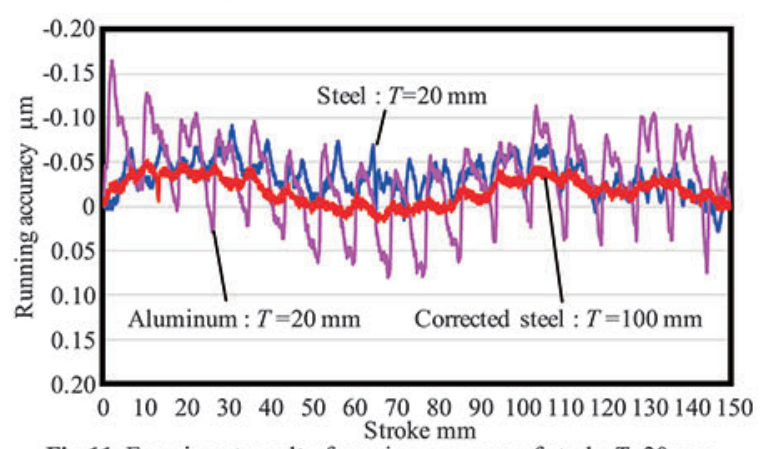

Fig.11 Experiment result of running accuracy of steel : $T=20 \mathrm{~mm}$, aluminum : $T=20 \mathrm{~mm}$ and corrected steel : $T=100 \mathrm{~mm}$ in the $z$ direction

(a) より，明らかにウェービングの大きさは鋼 : $T=100 \mathrm{~mm}<$ 鋼 : $T=20 \mathrm{mm<アルミニウム} \mathrm{:} T=20 \mathrm{~mm}$ の関係になっているこ とが確認できる.

(b) より,3 種類の実機テーブルのいずれにおいても波長 $2 \kappa D_{a}$ $=8.54 \mathrm{~mm}$ の基本波が確認でき, その半分の波長も確認できる. しかし, 基本波の 1.5 倍や 2 倍の波長はよく確認できなかった.

それと, アルミニウム : $T=20 \mathrm{~mm}$ で䫓著に約 $2.5 \mathrm{~mm}$ 位の波長 にピークがあり, その半分の整数倍に相当するピークが数か所 確認できるが, $\mathrm{LMBG}$ を含め本実験装置に該当するものは確認 できなかった. しかし，振幅はそれほど大きいとはいえないの で無視しうると考える. したがって, 図 11 における細かな振幅 はほぼウェービングであるといえる.

(c) より, 前報1) 同様ストロークと共にウェービング振幅值が 変化していることがわかるのと, はっきりと 3 種類の実機テー ブルによる差が確認できる. 表 3 に 3 種類の実機テーブルによ るウェービング振幅平均值 $w \alpha_{1}$ と補正済み鋼 : $T=100 \mathrm{~mm}$ を 1 としたときのそれぞれの比率をまとめた．補正済み鋼 : $T=100$ $\mathrm{mm}$ に対して鋼 : $T=20 \mathrm{~mm}$ で 2.1 倍, アルミニウム : $T=20 \mathrm{~mm}$ で 4.8 倍ウェービング振幅值が大きくなっている. LMBG シス テムにおいて一般的に高精度といわれるウェービング振幅值が

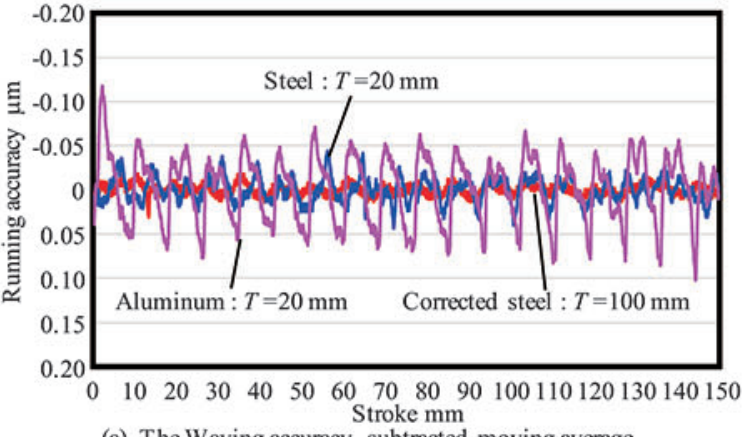

(a) The Waving accuracy subtracted moving average from measuring value

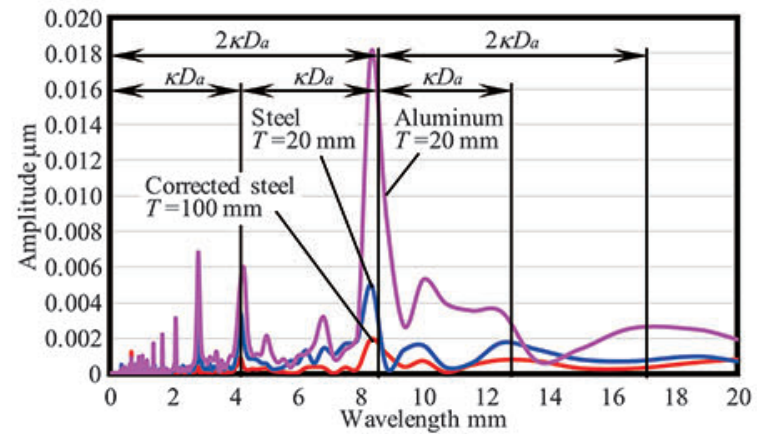

(b) Wavelength analysis result in (a)

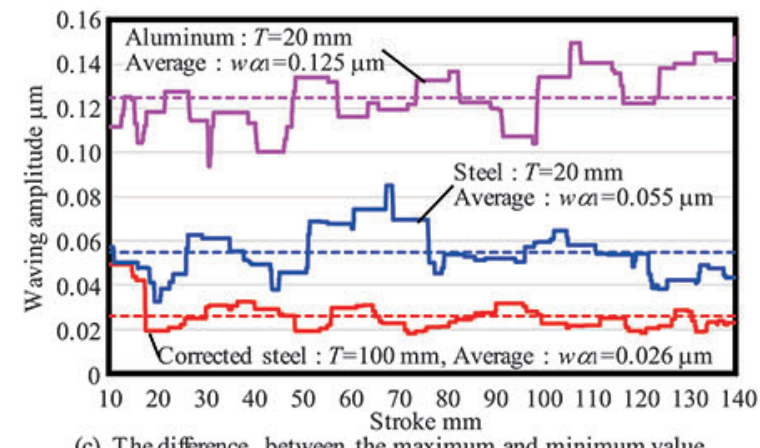

(c) The difference between the maximum and minimum value in the scope of $2 \kappa D a$ in (a)

Fig.12 Various analysis results in Fig. 11

Table 3 Experimental result of waving amplitude

\begin{tabular}{c|c|c}
\hline Table & $w \alpha_{1} \mu \mathrm{m}$ & Relative ratio \\
\hline Corrected steel : $T=100 \mathrm{~mm}$ & 0.026 & 1 \\
Steel : $T=20 \mathrm{~mm}$ & 0.055 & 2.1 \\
Aluminum : $T=20 \mathrm{~mm}$ & 0.125 & 4.8 \\
\hline
\end{tabular}

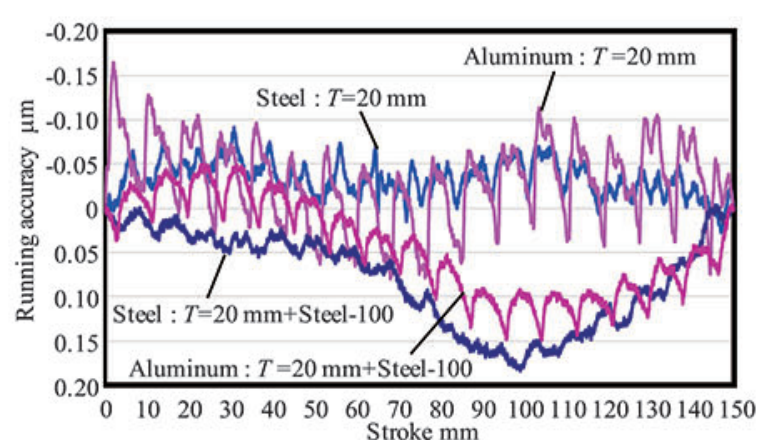

Fig.13 Experiment result of running accuracy in the $z$ direction

$1 / 100 \mu \mathrm{m}$ 台の值といわれており, 補正済み鋼: $T=100 \mathrm{~mm}$ で 0.026 $\mu \mathrm{m}$, 鋼 : $T=20 \mathrm{~mm}$ でも $0.055 \mu \mathrm{m}$ と高精度化が実現していたも のが, アルミニウム : $T=20 \mathrm{~mm}$ だと $0.125 \mu \mathrm{m}$ になり高精度化が 実現しなくなってしまうということである.

以上の結果より，実機テーブル剛性はウェービングに影響を 
与えており, 図 6 の関係からも, 予圧を付与した LMBG におい ては, 実機テーブル戌性が高いほどウェービング振幅值は小さ くなるということが明らかとなった.

さらに, 質量の影響を見るために, 鋼 : $T=20 \mathrm{~mm}$ とアルミニ ウム : $T=20 \mathrm{~mm}$ に鋼 : $T=100 \mathrm{~mm}$ の実機テーブルを固定せずに 載せただけの実験もおこなった. 図 13 にその結果を示す (それ ぞれ+Steel-100 と表記).これより鋼 : $T=100 \mathrm{~mm}$ の実機テーブ ルを載せたことによりウェービング振幅值が小さくなっている ことが確認できる. 特にアルミニウム : $T=20 \mathrm{~mm}$ に鋼 : $T=100$ $\mathrm{mm}$ を载せたを結果を詳細に見ていくと, 振幅の上凸部分が丸 くなり低くなっている様子がうかがえる．逆に下凸部分に変化 はあまり見られない.これは実機テーブルが上凸側へ変形しよ うとするときだけ大きな実機テーブル質量によって押さえられ 変形が抑制されたからと考えられる.また，ここでも真直度に 関しては鋼 : $T=100 \mathrm{~mm}$ を載せたものは大きく下凸の形状とな っていた. この理由も 5 章で考察する.

したがって, 実機テーブル剛性がウェービングに与える影響 とはその構造が異なるが, 実機テーブル質量もウェービングに 影響を及ぼしていて, 予圧を付与した LMBG においては, 質量 が大きいほどウェービング振幅值は小さくなるということがわ かった.

\section{5. 考察}

実験結果の, 図 9 に示した鋼 : $T=100 \mathrm{~mm}$ と, 図 13 に示した 鋼 : $T=20 \mathrm{~mm}$ とアルミニウム : $T=20 \mathrm{~mm}$ に鋼 : $T=100 \mathrm{~mm}$ の実 機テーブルを固定せずに载せただけの真直度が，全体として下 凸形状となっていたことに関しては, 質量違いが主要因である と考える. $T=100 \mathrm{~mm}$ 鋼製が約 $75 \mathrm{~kg}, T=20 \mathrm{~mm}$ 鋼製が約 $15 \mathrm{~kg}$, $T=20 \mathrm{~mm}$ アルミニウム製が約 $5 \mathrm{~kg}$ と $T=100 \mathrm{~mm}$ 鋼製だけが他 と比べて格段に大きい. それにより $z$ 方向下向きに変位が加算 されていたと考えられる.

さらに, ストローク後半部分だけにその傾向が強くみられる が, この理由は, 例えばレールを取り付けているベース底面の 精度が本ストローク後半部分が凹形状傾向となっており, 定盤 との間にわずかな隙間が生じていた可能性が考えられる. よっ て, その部分を実機テーブルが通過するときにその質量により ベースが沈みこんだのではないかと推測できる. もちろんべー スはボルトで固定しているが, ボルト本数は少なく, そのピッ チは広めであった. これら 3 つの結果の真直度の傾向が似てい ることからもそのことがうかがえる.

また, 別の要因も考えられる. 本実験装置は本研究テーマに も則しているのだが, 実機テーブルのキャリッジ取付面の加工 精度・傾きは 3 種類で異なると考えられる. そして, キャリッ ジ 4 個の上面と面同士を接触させたときに両者の精度・傾き違 いからすきまが生じ，それをボルトによって締結することによ
って実機テーブル側とキャリッジ側の両者が変形・変位するは ずである. そのとき, 3 種類の実機テーブルによるすきまの状 況違いと剛性違いによって個々のキャリッジ部に生じる不静定 モーメントは異なり, 変位も異なる. すると, 静的な状態にお ける LMBG 個々のキャリッジの姿勢が 3 種類の実機テーブル で異なっていることになり, 精度平均化効果2),3) の発現の仕方が 異なったからではないかということである. しかし, 今回の場 合は鋼 : $T=100 \mathrm{~mm}$ 実機テーブルを载せたことにより変化して いるので, 質量違いとベース精度の影響が主だと考えられる.

本研究では, LMBG システムの高精度化実現には欠かせない ウェービング現象に影響を及ぼす要因である実機テーブル剛性 について取り組んだが, 究極の目標は何にも影響を受けないで 高精度化が実現できる LMBG を開発することである. その目的 に向かい今後も研究を継続していく予定である.

\section{6. 結}

本研究から得られた結果を要約するとつぎのようになる.

(1) LMBG 単体のウェービングによって, LMBG システムの モデルテーブルは変形するということがわかった.

(2) LMBG システムのモデルテーブル変形量は, LMBG 部剛 性とモデルテーブル剛性とのバランスで決定され, モデル テーブル剛性が低く, LMBG 部の剛性が高いほど大きい.

(3) LMBG システムのウェービングは実機テーブル質量にも 影響を受けていることがわかり，予圧を付与した LMBG の場合, ウェービング振幅值は実機テーブル質量が大きい ほど小さい.

(4) 予圧を付与した LMBG システムにおいて, モデルテーブ ル変形を考慮したウェービング解析からモデルテーブル 変形量を求めることにより, 最終的に実現したいウェービ ング振幅值から,その条件を満たす実機テーブルの設計指 針を導いた.

(5) 予圧を付与していない LMBG システムにおいては, 最終 的に実現したいウェービング振幅値とモデルテーブル厚 さの関係は示せるが一意的には決められないので, 解析結 果から設計者が選択するか, モデルテーブル設計值を変更 しながら解析を繰り返して最終的に実機テーブルを設計 する手法を示せた.

\section{参 考 文 献}

1）高橋 微, 野口昭治: 直動ボールガイドの高精度化に関する研究 一クラウニングとウェービングの関係一, 精密工学会誌, 86, 3 (2020) 225.

2）清水茂夫：直怔ボールガイドシステムの負荷分布と精度・剛性 に関寸る研究，精密工学会誌，57, 10 (1991) 1814.

3）清水茂夫：直動ボールガイドシステムの精度平均化効果に関 する研究, 精密工学会誌, 58, 11（1992） 1873. 